\title{
A CONDIÇÃO SOCIAL DA CRIANÇA: REFLEXÕES SOBRE TRABALHO E AFETIVIDADE, PARA O ESTUDO DA INDIVIDUAÇÃO ${ }^{1}$
}

Douglas Facci ${ }^{2}$

Luiz Giani $^{3}$

\section{RESUMO}

Entre totalidade da vida social e subjetividade, as crianças sofrem, de um lado, as transformações do mundo do trabalho e, de outro, os transtornos da afetividade, como produto social. Este estudo é um resultado parcial de uma pesquisa sobre as relações entre pré-adolescentes - de duas turmas de $5^{\text {a }}$ série, de escola pública - e seus pais/responsáveis, de famílias de baixa renda e residentes em bairro da periferia de Maringá/Pr. O estudo de caso revela a gravidade das determinações sociais sobre o indivíduo, no contexto da nova ordem produtiva e nova sociabilidade. Arrastadas as instituições por um desmanche generalizado, sob o impacto da reestruturação produtiva (reengineering), os trabalhadores e sua prole enfrentam dificuldades e empecilhos, no processo de individuação. Captando as palavras e sentimentos das crianças, pode-se desvelar a sociedade que lhes é hostil, nos processos de "segurança ontológica" (Giddens); "habitus", "estratégias de desespero" e "conservação da violência" (Bourdieu); estímulos sociais (Vigotsky); "reengenharia do tempo" (Oliveira) e "autonomia negativa", um modo de resistência da criança que inclui, frequentemente, sua "má conduta", em resposta à hostilidade social. Como parte da longa história da divisão social nas duas esferas, trabalho e afetividade, esta era de desmanche e indeterminação realça a origem social dos obstáculos e sofrimentos, contudo, é do próprio estranhamento que emerge, pela resistência e enfrentamento, a dialética, sem a qual não avança o processo de individuação emancipadora da criança.

Palavras-chave: estrutura social, família, indivíduo, violência, resistência.

\section{CHILDREN`S SOCIAL CONDITION: REFLECTIONS ON LABOR AND AFFECTIVITY FOR THE INDIVIDUATION STUDY}

\begin{abstract}
Between the entirety of their social lives and their subjectivity, children suffer, in the one hand, by transformations in the labor world and, on the other hand, of affectivity disorders as a social product. This study is a partial result of a research on the relations between preadolescents - of two groups of $5^{\text {th }}$ grade, of public school - and their parents/guardians, of low income families who live on the outskirts of Maringá, Paraná. The case study reveals the seriousness of social determinations on the individual in the context of a new productive order and a new sociability. While institutions are forced to a generalized dismantling under the impact of productive restructuring - reengineering -, workers and their kids have to face hardships and hindering in their individuation process. By understanding children's feelings and words, one can figure out the society that is hostile to them in the processes of "ontological security" (Giddens); "habitus", "despair strategies" and "the conservation of violence" (Bourdieu); social stimuli (Vigotsky); "time reengineering" (Oliveira) and "negative autonomy", a way of resistance by the child that often includes his or her "bad behavior" as a response for the social hostility. As a part of the long history of social division in both areas, labor and affectivity, this age of dismantling and indetermination emphasizes the social source of these obstacles and sufferings. However, it is their own estrangement that brings forth, rising from resistance and confrontation, the dialectics without which the child individuation process cannot go forward.
\end{abstract}

Keywords: social structure, family, individual, violence, resistance. 
Meu espírito é milionário em sonhos e fantasias (PUCCINI. La Bohème). ${ }^{4}$ Ópios, edens, analgésicos / Não me toquem nessa dor / Ela é tudo o que me sobra / Sofrer vai ser a minha última obra (ASSUMPÇÃO, I. / LEMINSKI, P. Dor Elegante)

Milionário em sonhos e fantasias é o espírito da criança que, na sua vez e voz, é uma explosão de vida, nos planos biológico, afetivo e cognitivo. Sonhos, sofrimentos e resistência da criança, como agente social, são as motivações principais deste ensaio.

$\mathrm{O}$ processo de individuação é uma dialética entre corpo, mente e sociedade. Necessidades, carências, potencialidades e capacidades, ao serem exteriorizadas, constituem objetivações que, como qualquer objetivação social, tornam-se estranhas, voltam-se contra a própria pessoa, exigindo da sociedade e do indivíduo constantes ações de superação de obstáculos e opressões. O estranhamento, na individuação, é potencializado pela mercadoria e seu equivalente universal. A dialética da produção social faz da individuação um processo subordinado à mais universal das mercadorias: o dinheiro. Na pré-adolescência, etapa de aguçamento da sensibilidade perante o mundo do trabalho, as crianças sabem: (a) que dependem do trabalho dos pais, para obter os bens (mercadorias) necessários a suas necessidades e desejos; (b) que, em breve, serão os novos trabalhadores; e (c) que os sofrimentos do trabalho afetam sua vontade de ingressar e estar nesse mundo que exige a privação de brincar e a assunção de responsabilidades que limitam a liberdade. Já percebem, com evidência cada vez maior, que a labuta de seus pais/responsáveis deveria garantir aquilo que mais falta à família, qual seja, o dinheiro, vencedor de todas as carências. Já sentem que a vida de sofrimentos tem ligações com o transtorno que as condições de trabalho (e a tamanha falta do dinheiro) provocam no mundo das necessidades materiais, da afetividade e do sentido da vida.

Em seus fundamentos biológicos, cognitivos e emocionais, a história das possibilidades humanas é omnilateral, de afirmação e estranhamento de todos os sentidos do homem. Os órgãos humanos, nas relações dos homens entre si e com a natureza, "ver, ouvir, cheirar, saborear, pensar, observar, sentir, desejar, agir, amar", explicita Marx, enfim, todos os sentidos físicos e intelectuais são substituídos por objetivações, pela alienação de todos eles, no sentido de possuir, de ter, de propriedade privada. A vida da propriedade privada consiste em trabalho e criação de capital. "O ser humano tinha de ser reduzido a essa pobreza absoluta a fim de poder dar à luz toda sua riqueza interior" (MARX, 2007, s/ p.). Na individuação emancipadora, as objetivações transformam-se em sentidos humanos, a necessidade e a fruição perdem seu caráter egoísta. A natureza perde sua mera utilidade e sua utilização torna-se utilização humana (idem).

Nunca se valorizou tanto o vil metal, na sociedade afluente, pelo contraste entre a produção da abundância e a condição humana, na submissão extrema desta à lógica da mercadoria. Em qualquer classe social, a degradação da criança aparece de forma generalizada, não sendo exclusiva de crianças de rua ou em regime de trabalho, escravidão, prostituição, drogas e outras opressões. Mesmo em condições ditas normais de vida, no processo de individuação, a criança não escapa de uma inclusão social degradante.

Parte do arcabouço teórico de um estudo de caso para a dissertação de mestrado sobre a experiência da criança na contemporaneidade é, aqui, ampliada, com reflexões sobre a estrutura produtiva e a estrutura social da afetividade como campos sociais de determinação e estimulação. A criança é estimulada por motivações sociais, sem as quais ela não consegue desenvolver sua individuação para a autonomia. Embora a família seja o núcleo principal do sustento material e da afetividade das crianças, é ela própria objeto do 
desmantelamento social que deteriora sua função de mediadora de bens/mercadorias e afetos socialmente produzidos. A educação para a vida material e afetiva, bem como a formação da decisão e coragem da criança de servir-se do seu próprio entendimento dependem do compartilhamento entre família e escola. Se os pais/responsáveis não sabem o quê e como dizer/ensinar às suas crianças, parece que o locus principal do esclarecimento fica delegado à escola. A educação para a autonomia exige uma escola que não seja castrada e estéril, que resista aos mecanismos sociais de controle e heteronomia, quando ela própria é um desses mecanismos (ADORNO, 1995, p. 171). Aqui, nossas reflexões sobre a labuta e a afetividade, fundamentos primários da família e do processo de individuação, privilegiam as relações entre as crianças e seus pais/responsáveis. Assim, não abordaremos as relações entre criança e escola.

$\mathrm{Na}$ constelação de conceitos de produção social, individuação, estranhamento e emancipação, o paradigma trabalho é a atividade vital que, tornada objeto, é, ao mesmo tempo, expressão de liberdade, estranhamento e superação, como exposto no ensaio de Marcuse, inspirado nos Manuscritos de 1844, de Marx, ambos publicados em 1932:

A "atividade vital" do homem é "não uma determinabilidade, com a qual êle se confunde", como o animal; ela é "livre atividade", uma vez que o homem pode "diferenciar-se" da determinabilidade direta de sua existência, pode "torná-la objeto" para êle e superá-la; êle pode transformar sua existência em "meio", dar a si mesmo sua própria realidade, "produzir" a si mesmo e sua objetividade. É nesse sentido profundo (e não apenas no biológico) que deve ser compreendida a afirmação de que "o homem produz o homem", de que a vida humana é a vida propriamente "produtiva", "a vida que produz a vida". (MARCUSE, 1972, p. 32)

Nossos encontros com crianças, de 10 a 12 anos de idade, cursando a $5^{\text {a }}$ série, ocorreram em sala de aula e entrevistas. Elas residem na periferia urbana, entendida esta mais em seu aspecto social que pelo seu distanciamento do centro urbano e concentração em bairros pobres. Suas moradias, em condições sociais mais precárias, dividem o território, nos bairros, com imóveis relativamente valorizados (RODRIGUES et al., 2010). A maioria dos bairros antigos da cidade, como o próprio Borba Gato, onde moram boa parte das famílias entrevistadas, comportam pelo menos dois padrões econômicos. As famílias entrevistadas residem em moradias alugadas, próprias ou emprestadas. A renda familiar situa-se, em média, pouco além de dois salários mínimos. A cidade, Maringá, apresenta acentuada segregação sócio-espacial, com riquezas do capital concentradas no agro-negócio, comércio, indústria, imobiliário, bancos e universidades.

Nas falas dos pré-adolescentes, as expressões afetivas, em resposta às múltiplas formas da hostilidade social, são sentimentos de carência, perda, repressão, violência, discórdia, frustração, angústia, isolamento, insegurança, impotência, etc., e, relativamente, de felicidade, desejos realizados, auto-estima, reconhecimento, segurança, expectativa, sonhos, fantasias e idealizações. Suas experiências, pelas necessidades de reconhecimento e auto-afirmação, estão marcadas pelo sofrimento e ansiedade, no processo de justificação de seu ser e estar no mundo, incluindo diversas formas de comportamentos ditos desviantes ou incompreendidos, estratégias desesperadas, decorrentes da impotência das crianças em satisfazer suas necessidades materiais e espirituais. Faltam-lhes meios e instrumentos claros e adequados para uma individuação emancipadora, nas condições sociais das classes mais expropriadas. Não se trata de caso isolado. A desorientação e degradação da vida, sob a tragédia do desmanche, regressão e refluxo de conquistas históricas, como nas políticas públicas da infância, têm dimensões mundiais. É lugar-comum, dentro da recente 
sociologia da infância, apontar o paradoxo da precarização da infância na contramão da ampliação e consolidação dos direitos legais que objetivam a emancipação da criança como sujeito de direitos. Porém, ocorre, realmente, um refluxo nas políticas públicas para a infância, uma vez que os direitos das crianças são acompanhados pelo recuo de políticas que deveriam proporcionar-lhes proteção e assistência.

No final dos anos 70 Ariès assinalou que "existe o risco de que na sociedade de amanhã (...) a criança não siga concentrando em si, como acontece há um século ou dois, todo o amor e a esperança do mundo" (Ariès, 1986, p. 17). O historiador francês se refere a uma sociedade que estaria deixando de ser "child-oriented" como se verificara até os anos 60 e localiza nos EUA (onde principalmente se "rendera culto" à criança) o lugar onde mais se evidenciava o "refluxo" em relação à importância da infância ou o surgimento de uma franca hostilidade a seu respeito. Scheper-Hughes e Sargent (1998, p. 29) corroboram o que consideram ser a "previsão" feita por Ariès no fim da sua vida. Para as autoras, " $a$ idéia moderna de infância está desaparecendo e as crianças estão perdendo terreno" no quadro da recente proliferação de políticas públicas que lhes são hostis nos EUA, Canadá e Reino Unido. Políticas que estão rapidamente desmantelando o "welfare state" e instaurando, no contexto da nova economia global, a idéia de uma "sociedade sem deveres" ("duty-free society"): a retirada gradual do Estado das questões do bemestar de populações vulneráveis, especialmente mães e crianças. Assim, para aqueles que acreditavam na idéia moderna de infância como um tempo especial (a ser protegido) no ciclo da vida, a "sociedade sem deveres" é a maior tragédia do florescente neoliberalismo do final do século XX: a idéia de inocência e vulnerabilidade da criança - como uma idéia central no seu estatuto moderno - estaria sendo rapidamente substituída por políticas e atitudes hostis à criança nas sociedades contemporâneas. (MARCHI, 2009, p. 8-9)

\section{Individuação, degradação e emancipação}

A criação do indivíduo assemelha-se à criação artística, é paradoxal: submetendo-se à sociedade, o indivíduo sacrifica sua individualidade; inversamente, afastando-se da sociedade, pela recusa e isolamento, também, a sacrifica. Como a arte, a criança aproximase da sociedade, pela heteronomia, conformismo, rotina, submissão à repetição, à norma. É o coletivo sufocando a criança e a arte. Inversamente, ao repelir as normas, no dizer popular, a criança pinta o sete, é levada, insubordinada, sonha e deseja um mundo de liberdade, sob seu próprio controle. Neste afastar-se da sociedade, pela autonomia, insubmissão à rotina, à norma, também deixa de ser criança, pois a rotina, a experiência cotidiana, desejada ou não, é parte do conflito em que se forja a sociedade e o indivíduo.

A relação entre ser (ontologia) e ter (lógica da mercadoria), não é dualista, mas, sim, dialética. Afastamo-nos, neste ensaio, de métodos reducionistas, utilizados em práticas de aconselhamento, fundados na concepção de que um melhor bem estar do indivíduo esteja associado ao ser, contra o ter, e à auto-atribuição das causas de seus problemas e dificuldades. Optamos pela relação pendular, dialética, das ações humanas, trabalho, linguagem, sentimentos, ora, expressando heteronomia, curvando-se aos significados e valores socialmente impostos, ora, expressando autonomia, no esforço do indivíduo para agir de modo crítico e transformar-se de objeto em sujeito ativo. Possibilidades de autonomia e criatividade da criança dependem de estímulos sociais, para que ela possa 
acompanhar os avanços da emancipação humana, na sociedade em que vive, por mais difícil que lhe seja tornar-se sujeito ativo, nas carências e miséria que a castigam.

O trabalho como criação de capital torna cada vez mais visível a contradição do progresso, tecnologia e riqueza, limitadores e destruidores da condição humana. "O acúmulo do capital aumenta com a divisão do trabalho e vice-versa", quem o diz não é Marx, mas, sim, Adam Smith, citado por aquele, nos Manuscritos de 1844 (MARX, 2007). As categorias econômico-sociais manifestam-se através dos homens, porém, exercem um poder sobre os mesmos, acima de suas vontades, especialmente, das crianças, dificultando e impossibilitando a individuação emancipadora. $\mathrm{O}$ pensamento popular é sábio, quando diz que "quem trabalha não tem tempo para ganhar dinheiro" e a economia política sabe que retorna ao trabalhador uma parte mínima da riqueza por ele produzida, a parte necessária (ou insuficiente) à reprodução da força de trabalho, incluída nesta a prole. A energia do trabalho, vendida, é a mais degradada energia humana: força humana transformada em objeto, por assalariamento, quando não o próprio indivíduo, como escravo. Nessa contradição histórica, é gerada, em condições degradantes, a criatura que, aqui, nos interessa: a criança, por ela mesma, por suas palavras, por seus sentimentos.

A emancipação humana tem por base seu potencial e possibilidades criadas e desenvolvidas, historicamente. As necessidades biológicas, afetivas e espirituais, como produção social, encontram na sociedade contemporânea um nível crescente de hostilidade, empecilhos que afetam a todos, adultos e crianças. Veja-se a histórica conquista liberal do direito à propriedade e ao trabalho. Esse direito liberal não expressa incompatibilidade absoluta com a emancipação humana, porém, tem uma dimensão paradoxal que restringe e impossibilita o que ele deveria garantir, isto é, o real acesso de todos à propriedade e ao trabalho. Permanece servil à economia de livre mercado que privilegia os proprietários contra os banidos da propriedade e do trabalho, confinados na miséria e na pobreza (expropriados, sem terra, sem teto, sem escola, sem universidade, sem saúde, sem família, em trabalho precário, subempregados, desempregados, em regime de trabalho escravo, etc.). A hostilidade social afasta a criança das possibilidades humanas criadas historicamente, disponíveis para as crianças cujas condições sociais privilegiadas já estão garantidas, por nascimento e riqueza herdada. Individualmente, poucas pessoas podem atingir níveis elevados de emancipação humana. A maioria não consegue superar os obstáculos sociais. O indivíduo não tem controle sobre as condições de vida e trabalho que o oprimem, da mesma forma que não escolhe seu próprio nascimento, entre nascer de operário ou de banqueiro. Uma nova sociedade submeteria as condições sociais do desenvolvimento social e do movimento dos indivíduos ao controle destes que, assim, teriam os meios de cultivar seus dotes e possibilidades em todos os sentidos.

As tensões entre trabalho assalariado e trabalho doméstico vêm provocando transformações violentas nos laços afetivos formadores da individuação. O recente desmanche geral da estrutura produtiva e da política arrasta a mulher e a família, expandindo sobre estas as violências históricas, com mais deterioração do tempo e trabalho maternos, aí incluído seu rapto pelo trabalho assalariado, sacrificando a segurança ontológica necessária à individuação da criança. As alterações da divisão do trabalho social impõem novos modos de reprodução biológica e social, desde o planejamento da prole ao seu sustento, proteção e formação omnilateral. A cultura da infância degradada, desde o mundo da produção (e consumo) material até o mundo da afetividade e cultura imaterial (espiritual), está engolfada pelo esvaziamento das relações sociais, a destruição da sociabilidade, em decorrência de interesses os mais poderosos que mantem a sociedade sob sua administração total(itária), como a que regula a desregulação, o desmanche.

A hiperindividualização conduz à destruição do próprio indivíduo, em decorrência da exacerbação do individualismo, na medida em que "cada um obstaculiza reciprocamente 
a afirmação do interesse do outro, e desta bellum ommium contra omnes, em lugar de uma afirmação universal, resulta antes uma negação universal" (MARX, 2011, p. 185). Se o recente desmanche deixa à deriva as instituições, como a família, a escola, a classe social e o sindicato, não é menos verdade que a espinha dorsal da sociedade - a estrutura produtiva - adquire maior resistência, beneficiada pela desregulação da produção, como um barco firme e veloz, com remadores fiéis e bem treinados para resistir e ultrapassar as maiores tempestades. Esse barco segue pelo oceano - o capitalismo tardio - abundante de cadáveres e restos vivos de remadores desnecessários, descartados, a bem do sucesso do projeto. Com metáforas desse tipo, Adorno e Horkheimer encontraram inspiração em Homero: o rei Ulisses entope de cera os ouvidos de seus trabalhadores/remadores, para que não escutem o canto das sereias, de felicidade e prazer, e, assim, não se distraiam do trabalho. $\mathrm{O}$ trabalho efetua-se "sob coação, desesperadamente, com os sentidos fechados à força" (ADORNO e HORKHEIMER, 1985, p. 40). Algo da metáfora está, hoje, alterado: o trabalho repressivo, na sociedade afluente, é obtido mais por sedução, pois o Ulisses contemporâneo faz todos remarem com mais eficiência, os ouvidos destampados, na escuta das uiaras enganosas que os enfeitiçam e proporcionam recompensas prazerosas.

Aguçada a sensibilidade infanto-juvenil para consumir, o pouco dinheiro das famílias adquire um poder cada vez menor, em dimensão oposta à massa da produção que se agiganta, assedia e seduz as crianças e adultos. Marx já havia denunciado esse processo desumano, de engano, roubo, depravação, por efeito da ilusão, o fetiche da mercadoria:

Com a massa de objetos, por conseguinte, cresce também o reino de entidades estranhas a que o homem se vê submetido. Cada novo produto é uma nova potencialidade de mútua fraude e roubo. $\mathrm{O}$ homem torna-se cada vez mais pobre como homem; ele tem necessidade crescente de dinheiro para poder apossar-se do ser hostil. O poder de seu dinheiro diminui na razão direta do aumento do volume da produção, i. é, sua necessidade cresce com o poder crescente do dinheiro. A necessidade de dinheiro é, pois, a necessidade real criada pela economia moderna, e a única necessidade por esta criada. A quantidade de dinheiro torna-se cada vez mais sua única qualidade importante. Assim como ele reduz toda entidade a sua abstração, também se reduz a si mesmo, em seu próprio desenvolvimento, a uma entidade quantitativa. Excesso e imoderação passam a ser seu verdadeiro padrão. Isso é demonstrado subjetivamente, em parte pelo fato de a expansão da produção e das necessidades tornar-se uma subserviência engenhosa e sempre calculista a apetites desumanos, depravados, antinaturais e imaginários. A propriedade privada não sabe como transformar a necessidade bruta em necessidade humana; seu idealismo é fantasia, capricho e ilusão. (MARX, 2007, s/ p.)

O custo e sofrimento dos filhos não diminuíram, com o progresso e a tecnologia. As famílias extensas de escravos ou de colonos, da produção agrário-exportadora, cederam à minúscula família nuclear, de insustentável preço da prole, com nenhum filho ou, quando muito, dois ou três. A estrutura produtiva mundial, três vezes superior ao necessário para alimentar a população do planeta, é a mesma responsável por três milhões de crianças mortas por subnutrição, ao ano, e uma população de um bilhão de famintos. A barbárie faz emergir a consciência sensível, clamando por um novo modo de produção social, voltado para o atendimento das necessidades humanas, para a emancipação plena de todos:

[...]o processo de individuação alcançaria seu mais alto grau por meio justamente da socialização do indivíduo em circunstâncias ausentes de 
alienação e que permitissem, portanto, a efetivação, na existência individual, da universalidade e da liberdade alcançadas num dado momento histórico pela riqueza do gênero humano. (DUARTE, 2006, p. 611)

\section{Reestruturação produtiva, na sociedade tecnológica: hiperindividualização e precarização da vida, da autonomia e da crítica}

A hiperindividualização, mecanismo da lógica cultural neoliberal, retira a responsabilidade da estrutura social sobre as precárias condições de vida do indivíduo geradas por essa mesma estrutura social. A transferência de responsabilidades para os ombros do indivíduo isenta a sociedade dos problemas que ela mesma cria.

A precariedade da vida é socialmente produzida e imposta aos nascituros, crianças e pré-adolescentes, contra a vontade e esforço dos trabalhadores, que não conseguem vencer grande parte das barreiras sociais, pela impenetrabilidade destas. Limitações, inabilidades e incapacidades individuais são, em grande parte, produtos sociais, quando não o são, totalmente. Vulgarmente, é comum o uso de expressões do tipo "não querer trabalhar", "menor esforço", "preguiça", "vagabundagem", destinadas a atribuir o desemprego a um ato individual, subjetivo. Alguém afirma que o emprego segue plenamente aquecido, na cidade: "só não trabalha quem não quer", enquanto um diretor da Agência do Trabalhador (que anuncia 355 vagas para auxiliar de linha de produção) aponta razões objetivas para a "sobra" de vagas: falta de qualificação, baixos salários e regimes desgastantes (O DIÁRIO, 2013, p. A1).

Se os trabalhadores não têm qualificação, esta condição deriva, antes de tudo, da divisão do trabalho social e do controle do grande capital sobre a estrutura produtiva. A lógica de mercado não é capaz de absorver o grande excedente de trabalhadores não qualificados e não deposita interesse na sua qualificação geral como necessidade humana.

A suspensão do Estado interventor e regulador significa, efetivamente, mais liberdade e autonomia para o capital. Aparentemente, isto significa mais liberdade e autonomia extensivas a todas as classes sociais. Na realidade, o mercado é caótico, amplia as necessidades, carências e frustrações dos trabalhadores, como a dita exclusão social. Trata-se de uma suposta exclusão, pois não passa de um processo de redefinição destinada à "inclusão degradante", "redefinição de posições e localizações das pessoas no mundo do trabalho, particularmente, e na vida social, em geral". São dificuldades, modos e problemas de uma "inclusão precária e instável, marginal", tentativas de reaplicação de direitos ao "excluído", como o direito ao trabalho e seu retorno à condição passiva, condição "subalterna de reprodutores mecânicos do sistema econômico, reprodutores que não reivindiquem nem protestem em face de privações, injustiças, carências" (MARTINS, 2003, p. 17-26). A legislação de direito ao trabalho perde força, por força da automação.

Para eliminação do excesso de mão de obra, "o modelo japonês de gestão ensina que uma economia competitiva é aquela que consegue eliminar todo e qualquer 'excesso' de pessoa, para que a gerência possa contabilizar unicamente o trabalho que contribui diretamente para criar valor" (TEIXEIRA, 2009, p. 128). A partir das pesquisas do Massachusetts Institute of Technology (MIT), nos anos 80, a competitividade atingiu elevados índices, sob o nome de reengineering (reengenharia). Abandonou-se a rigidez da regulação fordista. Novas necessidades administrativas foram identificadas. Transformouse o trabalhador especializado em trabalhador coletivo, flexível, na execução de diferentes tarefas, sem a divisão rígida de ocupações. "Na realidade, trata-se de um processo de enxugamento nos custos das empresas, que vai desde a reformulação do seu layout até a redução e eliminação de postos de trabalho. Tudo é feito em nome da economia de salário e 
outros custos" (idem, p. 121). Destruir a resistência dos trabalhadores, sindicatos e leis de proteção ao trabalho, é uma operação de desmanche:

Para realizar essas transformações na organização interna do processo de trabalho, o capital precisa enfrentar a resistência da classe trabalhadora. (...) Para tanto, é preciso remover os obstáculos institucionais que anteriormente regulamentavam a compra e venda da força de trabalho. Daí a ofensiva do capital contra os sindicatos e toda e qualquer legislação de proteção do trabalho. Por isso, o desmonte do Welfare State, com seu excesso de regulamentação burocrática e padronizada, tem que entrar na ordem do dia. A liberdade de contratação e de negociação exige o afastamento do Estado; sua ausência como mediador dos conflitos entre capital e trabalho. (...) Daí a necessidade de desmantelamento das estruturas do Estado Social. Portanto, redivisão social do trabalho, "reestruturação produtiva" e neoliberalismo constituem momentos de um todo; determinações de uma forma de produção de mercadorias, que só pode se afirmar, enquanto tal, se essas condições se fizerem presentes. (TEIXEIRA, 2009, p. 112-113)

Holloway relata a campanha publicitária de lançamento do carro da Nissan, em 1986, e os comentários da empresa sobre o contentamento e consenso dos trabalhadores:

Aqui se tem uma fábrica onde administradores e trabalhadores igualmente vestem casacos brancos e dividem a mesma cantina, onde administradores e trabalhadores são igualmente jovens (...), uma companhia onde nunca houve greve, onde os sindicatos não são proibidos, mas são desnecessários porque os trabalhadores desfrutam de boas condições e se identificam com os objetivos da companhia. (HOLLOWAY, apud TEIXEIRA, 2009, p. 117)

Na lógica do neoliberalismo, a relação do trabalhador é com o poder impessoal do mercado e deve somar ousadia e competência individual para consecução de benefícios, em contraste com as lutas históricas, coletivas, por condições de trabalho, salários, políticas trabalhistas e de seguridade. O desaparecimento da política é uma das conseqüências mais devastadoras desta era da incerteza, momento em que a reestruturação produtiva provocou enorme impacto sobre a política, sob o governo Collor. Francisco de Oliveira, em Política numa era de indeterminação: opacidade e reecantamento, observa que, durante o regime militar e a redemocratização, as "linhas de força" ainda se manifestavam, com certa clareza, possibilitando a política, o dissenso (OLIVEIRA, 2007). O período que antecedeu o governo Collor foi uma época de "forte invenção política". Tanto a economia quanto a cultura possuíam antecedentes históricos fundados no nacional-desenvolvimentismo. A tutela estatal sobre o proletariado, durante a ditadura de 64, era uma herança do estadonovismo getulista. O regime militar impulsionou a nacionalização de setores produtivos e a tutela estatal, no tripé desenvolvimentista de empresas estatais, privadas nacionais e multinacionais. As classes populares, um novo sindicalismo e novos movimentos sociais forçaram o Estado militar a uma nova política e nova sociabilidade, uma reinvenção cuja base social podia ser reconhecida pelas linhas de força ainda existentes. Com a redemocratização, essas linhas de força mantinham-se presentes na Nova República: "Seu programa foi a tentativa de criar uma política que fosse a tradução dos novos interesses criados pela intensa expansão capitalista, recuperando as linhas de força entre classe e representação, o que conferia previsibilidade à política" (OLIVEIRA, 2007, p. 22). Porém, as linhas de força tiveram vida curta. Desapareceu a política. As relações 
entre classe, interesses e representação foram desmanteladas. O "cerne da indeterminação" reside, talvez, nesse "desmanche", no violento impacto da reestruturação produtiva sobre a política, diz Oliveira.

Na década da reengineering, anos 1980, os EUA haviam saído da pior recessão, em cinco décadas (desde o crack de 1929). Porém, com ou sem recessão, a pobreza é constante. No filme God Bless the Child (1988), é assustadora a mensagem: "32 milhões de pessoas vivem na pobreza nos Estados Unidos, hoje. 13 milhões deles são crianças". Na mesma ocasião, o salto para a reestruturação produtiva atingia a população brasileira de raízes, predominantemente, rurais e interioranas: desde as décadas de 1950-1960, a população urbana crescia, mais por efeito do êxodo/expulsão de colonos, pequenos sitiantes, meeiros, parceiros, etc., em grande parte, transformados nos bóias-frias. Com o país em desenvolvimento, o regime militar difundia promessas de liberdade e felicidade, com slogans do tipo "Pra frente, Brasil!", "Ame-o ou deixe-o", "Brasil grande", "Brasil, país do futuro", "Meu Brasil, eu te amo". Em poucos anos do processo de redemocratização, as linhas de força entre classe e representação perderam potência, deixando irreconhecível o elemento antagônico, na estrutura de classes sociais. Hoje, com a reengineering e o esvaziamento da política, não se acusam as classes sociais geradoras de riqueza, opulência e miséria e, quando muito, tenta-se aliviar a dor e sofrimento dos pobres. Múltiplos programas sociais, como o Bolsa família e o plano de elevação do salário mínimo, destinados a retirar da miséria e pobreza 30 milhões de pessoas, parecem dar legitimidade ao atual lema oficial, "país rico é país sem pobreza". Em três décadas de reengineering e desmobilização popular, a dominação conta com a servidão voluntária, trabalhadores identificados como colaboradores, pois, é assim que são chamados pelas suas empresas.

Desmantelada a intervenção estatal na economia, os trabalhadores perderam garantias trabalhistas conquistadas, historicamente, desde o governo Vargas. Falido ou enfraquecido o intervencionismo, o Estado concentra-se na implementação de bens e serviços sociais, compartilhando ações com a sociedade civil, empresas (que oferecem planos de saúde, aposentadoria, seguridade, etc.) e Terceiro Setor sem fins lucrativos. A participação popular é reduzida ou inexistente. Redefinido o papel do Estado como poder normativo e regulador da vida social, tenta-se abrir espaços de participação da sociedade civil. A regulamentação das políticas sociais está expressa nos conselhos federais, estaduais e municipais, nas áreas da saúde, assistência social, educação, infância e adolescência. São deste período a Lei Orgânica da Saúde (1990), a Lei Orgânica da Assistência Social (1993), a Lei de Diretrizes e Bases da Educação Nacional (1996) e o Estatuto da Criança e do Adolescente (1990). Pelo fortalecimento das políticas públicas, tenta-se garantir condições básicas de moradia, alimentação, saúde, educação, proteção à mulher e à criança, quotas étnicas no trabalho e na universidade, preservação ambiental, etc.

Procura-se compensar as perdas trabalhistas com promessas de qualidade de vida e felicidade, junto a parcelas cada vez maiores dos trabalhadores, que tendem a reagir de modo massificado, consensual, pelo conformismo, reduzidos os níveis de consciência e politização. A massa que, outrora, podia ser mobilizada como instrumento de insatisfação e rebeldia, agora, sente-se liberta em suas formas de suprir necessidades e desejos, no mundo sedutor das mercadorias, através do consumo, da proteção e da assistência recebidas, via programas sociais. A sociedade "envolve seus membros primariamente em sua condição de consumidores, e não de produtores" (BAUMAN, 2001, p. 90). A massa de trabalhadores interessa cada vez menos à sociedade tecnológica, dita sociedade do conhecimento: o excesso de força de trabalho é tratado como questão contábil e de culinária, uma incessante queima empresarial de gordurinhas (sangue vivo do trabalhador), para não esclerosar as veias da produção lucrativa. No pós-Segunda Guerra Mundial, Marcuse constatava a geração de um homem "unidimensional", conformista, esvaziadas as possibilidades de 
recusa, crítica radical e transformação qualitativa, na sociedade afluente. "O aparato produtivo tende a tornar-se totalitário no quanto determina não apenas as oscilações, habilidades e atitudes socialmente necessárias, mas também as necessidades e aspirações individuais" (MARCUSE, 1982, p. 17-18). Na sociedade antagônica ao Estado, as categorias indivíduo, classe, trabalho e família constituíam esferas e forças vivas que, hoje, estão integradas às condições estabelecidas, parecendo confirmada a "profecia": "com a crescente integração da sociedade industrial, essas categorias estão perdendo sua conotação crítica, tendendo a tornar-se termos descritivos, ilusórios ou operacionais" (idem).

O estado de precariedade e isolamento social do trabalhador é um cenário de inseguranças e incertezas que avança do mundo do trabalho à sua vida privada, familiar. Integradas à nova ordem de reestruturação produtiva e consumo, as crianças entrevistadas utilizam critérios para avaliar seus pais, por aquilo que os pais lhes compram e não por aquilo que recebem na condição de seres humanos. A mediação do consumo, sob a lógica da mercadoria, materializa as relações entre pais e filhos, provocando o afastamento, o distanciamento psicossocial entre eles, o seu isolamento humano existencial, agravado pelo individualismo e violência doméstica, que reforçam o medo, carência afetiva, perda da confiança, conspirando contra o avanço da intimidade e afetividade.

Com o desmantelamento geral da estrutura produtiva, do sindicato e da política, a cisão e a cizânia estenderam-se do mundo do trabalho ao interior da família e da infância. A pequena parcela de trabalhadores qualificados, bem sucedidos, contrasta com a massa de trabalhadores com pouca ou nenhuma qualificação, mais premida pelo desemprego, baixos salários, intensificação da labuta e a dupla jornada de trabalho das mães que migram em massa do lar para o mercado de trabalho. A família reduz a prole, frente ao custo da criação e sustento e ao medo de colocar filhos no mundo para sofrer. As relações capital/trabalho não pressupõem mais a grande prole, aquela da classe prole(tária), e, nem mesmo, a pequena família. A nova ordem privilegia o trabalhador desimpedido, pronto para se adaptar e se readaptar às necessidades da produção, sem protesto, sem resistência. "O mercado de trabalho que, na primeira modernidade, pressupunha a 'prole` e, portanto, uma família 'por detrás` do trabalhador assalariado, na modernidade reflexiva pressupõe uma sociedade isenta de famílias e casais" (MARCHI, 2009, p. 10). Como diz Beck, "o indivíduo do mercado é o indivíduo sozinho, desembaraçado de todo empecilho relacional, conjugal ou familiar. A sociedade de mercado a que chegamos é também uma sociedade sem crianças" (BECK, apud MARCHI, 2009, p. 10). É a consumação do desmantelamento da família e da infância. A nova ordem não hesita em expulsar o trabalhador casado, tema de estudos sobre periferias, como no caso de Sapopemba (São Paulo), onde vivem 300 mil pessoas. Em Fronteiras de tensão: política e violência nas periferias de São Paulo, fala-se das perdas e falta de perspectiva:

As mudanças econômicas dos anos 1980 e 90 atraíram novas famílias, desta vez sem histórico de trabalho estável nem projeto de ascensão claramente formulado. Como diz Feltran, "não havia marido empregado na indústria nem planos claros de educar os filhos para fazê-los doutores e saírem dali um dia. Não havia, tampouco, a mesma ênfase no associativismo, tão marcante na trajetória operária que redunda no movimento sindical, forte no distrito". (LUCENA, 2012, p. 4)

A política e a cultura - mesmo que não representem nenhum valor para os neoliberais e o pessoal do mercado - são instâncias privilegiadas para o aparato econômico:

[...]para eles a filosofia política não tem nenhum valor (pelo menos após se livrarem dos argumentos do inimigo marxista e coletivista) e a 
"política" significa agora simplesmente o cuidado e a alimentação do aparato econômico (nesse caso, o mercado, em vez dos meios de produção organizados e de propriedade coletiva). (JAMESON, 1996, p. 273)

A família não resiste à força totalizadora do mercado. Em sua análise da ideologia do mercado e a lógica cultural do capitalismo tardio, Jameson observa a relação entre a realidade e o modelo totalizador de visão do mercado proposto por Becker, em $A n$ economic approach to human behavior. Para Becker, o modo racional do casamento é um elemento da análise de mercado. As pessoas se juntam para maximizar "o output total de mercadorias do lar, com respeito a todos os outros casamentos, não importando se aí se trata de um aspecto financeiro (como salários e renda de patrimônio), ou genético (como altura e inteligência), ou psicológico (como agressividade e passividade)", diz Becker (apud JAMESON, 1996, p. 274). Esse modelo de produção totalizador, que permite entender todo tipo de comportamento humano, é um modelo realista e escandaloso de mercado, observa Jameson. Becker sintetiza: "estou dizendo que a abordagem econômica nos oferece uma moldura unificada valiosa para entender tudo no comportamento humano" (idem). Eis a descrição central de Becker:

$\mathrm{O}$ enquadramento da função produtiva do lar enfatiza os serviços paralelos feitos por firmas e pelos lares como unidades organizacionais. Do mesmo modo que a firma típica, analisada na teoria standard de produção, o lar investe em capital ativo (as economias), em equipamentos (os bens duráveis) e no capital contido em sua "força de trabalho" (o capital humano dos membros da família). Como uma unidade organizacional, o lar, como a firma, entra na produção usando esse trabalho e esse capital. Cada um é visto como maximizando sua função objetiva, sujeito a seus recursos e limitações tecnológicas. O modelo de produção não apenas enfatiza que o lar é a unidade básica de análise apropriada na teoria do consumo, como também traz à tona a interdependência das várias decisões do lar: decisões sobre o suprimento de trabalho familiar, sobre o tempo e sobre os gastos em uma análise de um só período de tempo, e decisões sobre o casamento, o tamanho da família, o envolvimento da força de trabalho e os gastos em bens e em investimentos de capital humano em uma análise de ciclo de vida. $\mathrm{O}$ reconhecimento da importância do tempo como um recurso escasso no lar desempenhou um papel integral no desenvolvimento das aplicações empíricas da abordagem da função produtiva do lar. (BECKER, apud JAMESON, 1996, p. 274-275)

Nesse modelo realista de produção, "o consumo é explicitamente descrito como a produção de uma mercadoria, ou de um bem específico; em outras palavras, um valor de uso que pode ser qualquer coisa", diz Jameson. Para Becker, "o output de mercadorias não é a mesma coisa que o Produto Nacional como é normalmente medido, mas inclui filhos, companheirismo, saúde e uma série de outras mercadorias" (idem).

Não acreditamos que esse modelo de racionalização produtiva da família possa ser aplicado, sem ressalvas, às famílias que entrevistamos, situadas em segmentos sociais precários. A lógica racionalizadora do modelo faz mais sentido em se tratando das classes médias para cima. A família de classes populares parece mais um caldeirão em ebulição e menos um poço de frieza e racionalidade. Porém, temos que concordar com Jameson, quanto à objetivação mercadológica que engaiola toda e qualquer família, quando todas as atividades humanas vão sendo subordinadas pela lógica da mercadoria. 
A expropriação do trabalho e do tempo do trabalhador é a mais comum forma de dominação contemporânea, que pode estar no cerne da ansiedade (BOURDIEU, 2001). Na educação da sensibilidade, "o homem apreensivo assolado pela pobreza não tem disposição para o espetáculo mais belo[...]" (MARX-ENGELS, 1979, p. 52). Obter êxito na promoção da autonomia da criança é um processo extremamente difícil, que requer dos pais/responsáveis que suas próprias ansiedades e condutas, por serem referenciais para a criança, sejam reflexivas e controladas, sob o crivo do entendimento crítico, do esclarecimento, em meio às contradições vivenciadas. A superação da pobreza material não é suficiente para a formação da individuação omnilateral e emancipadora, que depende, também, da natureza das relações que os pais/responsáveis e as crianças estabelecem com as instituições que atuam sobre a mente, como a escola, igreja, partidos políticos, tecnologias da informação e comunicação, ciência e arte. Prevalecem as ideologias que reproduzem a sociedade dominante, mas, a existência da opressão gera possibilidades de esclarecimento, pela pedagogia crítica, pedagogia do oprimido, pedagogia contra a barbárie e para além do capital, entre outras denominações.

A emancipação, no processo de individuação, desde a menoridade, pressupõe um sujeito de rebeldia. A opressão sobre corpo e mente funciona como forja de inconformismo, revolta e crítica, contra as formas de exclusão e inclusão degradante:

[...]rigorosamente falando, não existe exclusão: existe contradição, existem vítimas de processos sociais, políticos e econômicos excludentes; existe o conflito pelo qual a vítima dos processos excludentes proclama seu inconformismo, seu mal-estar, sua revolta, sua esperança, sua força reivindicativa e sua reivindicação corrosiva. (MARTINS, 2003, p. 14)

A emancipação da espécie não se efetiva pelo somatório de planos individuais. Universalizar a riqueza - material e espiritual - é condição necessária para a realização de todos os homens, sem exceção. Envolve transformação qualitativa das relações antagônicas entre classes sociais, desde as mais expropriadas até as dominantes. A superação é geral, na dimensão do trabalho expropriado e na dimensão do pólo expropriador, o capital.

Em Reengenharia do tempo, Rosiska Darcy de Oliveira critica a reengineering, pelo enorme prejuízo aos trabalhadores e suas famílias. $\mathrm{O}$ aviltamento de suas vidas faz lembrar a escravidão. Desfazer tal processo será um impacto semelhante ao abolicionismo. Se a expropriação do trabalho e do tempo dos indivíduos é a mais comum forma de dominação contemporânea, entra no cálculo da destrutividade o tempo roubado da afetividade e as variadas formas de sofrimento e carências, quando a criança é alvo das ações de desatenção, ausência e deserção dos pais/responsáveis, em especial, as mães trabalhadoras. Cuidar dos filhos não é trabalho que espera por remuneração. São atos que dão trabalho, ocupam tempo, que garantem a preservação da vida, "onde os gestos se fazem e se retribuem por carinho" (OLIVEIRA, 2005, p. 3-5). As empresas modernizaram a tecnologia e métodos de gestão para tornarem-se competitivas, "mexeram em seus horários em função dos interesses da produção, mas mantiveram-se, em sua esmagadora maioria, cegas e alheias à existência da vida privada de seus empregados" (idem, p. 11). "Parques industriais de última geração não rimam com o impressionante atraso no tratamento do que chamam de capital humano". Trata-se de "uma das maiores e mais escandalosas instâncias de exploração de trabalho humano que a história conhece" (idem, p. 12). A produção repressiva descarta a questão, com arrogância, devolvendo-a para a vida privada como se fosse um problema de negociação conjugal, problema pessoal. A autora conclui que se trata de uma destruição em massa do psiquismo humano, um processo "que resulta do estilo de 
vida de milhões de crianças". "Uma reengenharia do tempo é urgente. Quando se fizer, atingirá a sociedade com o mesmo impacto do fim da escravidão" (idem, 2005, p. 9-14).

\section{Criança e individuação, na metrópole: sofrimento, prazer e expectativas, na (de)formação para o trabalho e o consumo}

Entender o indivíduo exige que se coloque em primeiro plano a totalidade social e vice-versa: "a totalidade social se expressa nas ações individuais cotidianas, na tensão entre o indivíduo e sua genericidade posta como possibilidade histórica na contradição: Capital Trabalho - Emancipação Humana" (GONZÁLEZ, 2003, p. 68).

O trabalho e a afetividade, na estruturação da família, são objetivações sociais constituintes do fundamento da vida e, assim, entendê-los é uma exigência para o entendimento da individuação. Nas sociedades tecnológicas, a criança é atingida pela competitividade e lucratividade da estrutura produtiva que, de um lado, expulsa a mão de obra excedente, deteriorando as condições da família, e, de outro, submete a criança ao assédio prazeroso e compulsivo do consumo de mercadorias, ao domínio de apetites artificiais e desumanos, obstruindo a afetividade e o orçamento familiar. Obstruídas as condições econômicas e afetivas da família de trabalhadores de baixa qualificação e remuneração, as crianças sobrevivem em permanente risco. Elas não costumam resistir ao consumo compulsivo, que deteriora o processo de individuação e a economia familiar. $\mathrm{O}$ sofrimento, em suas múltiplas formas, também avança sobre as famílias que atingem níveis de opulência, mas esta não é a condição das crianças, em nosso estudo de caso. A maior parte das crianças entrevistadas têm computadores, videogames, celulares e mais bens materiais do que utilizam, mas, certamente, muito menos do que desejam. Sob muitos aspectos, essas crianças são bastante representativas da maior parte das crianças do Brasil, em sua faixa etária. Suas famílias têm uma renda de dois a cinco salários mínimos, mas, muito mais para dois do que para cinco. Suas moradias estão situadas na periferia urbana, onde a acentuada segregação socioespacial compartilha o mesmo território entre moradias de alto e baixo padrão. Mansões fazem vizinhança com moradores de baixa qualificação e estes não são exclusivos em nenhuma área do município. A segregação socioespacial é mais acentuada entre a periferia do município de Maringá e a área interurbana, nas fronteiras com outros municípios (RODRIGUES et al., 2010, p. 38).

As expectativas das crianças são muito precárias, incertas, em torno do que "querem ser quando crescer", "vão ser", "poderão ser". A preparação para a idade legal para o trabalho é, frequentemente, uma experiência afetiva da barbárie. A sociedade faz de suas pequenas criaturas vulcões de sentimentos/sofrimentos atormentados, de racionalidade mais obscurecida que lúcida, no esforço que elas fazem para "se realizarem" e entender esse mundo que lhes é, ao mesmo tempo, tão íntimo e tão estranho e hostil. Em meio a tantas agruras, há depoimentos em que se dizem felizes. Assim, sentimentos de coragem confinam-se na afeição pela vida como ela é, entre a coragem de viver, a esperança e o conformismo que o filósofo chamou de servidão voluntária. Na condição de objetos da produção de mercadorias, as crianças tanto contribuem para equilibrar o consumo com a oferta, preservando e ampliando as taxas de lucro, quanto para reproduzir sua classe de futuros trabalhadores em condições emocionais de conformismo, satisfação e otimismo. Nessas objetivações, a família e a escola não conseguem controlar os impulsos estimulados pelas mercadorias, em meio à abundância de prazeres geradora, simultaneamente, de satisfação e sofrimento. No contexto da revolução industrial, discorrendo sobre necessidades, produção e divisão do trabalho, Marx já alertava para o excesso e a nãomoderação que se tornavam a verdadeira medida da necessidade do dinheiro, pois "a expansão dos produtos e das necessidades se transforma em subserviência engenhosa e 
sempre baseada nos apetites inumanos, corrompidos, antinaturais e fantasiosos" (MARX, 2007, s/ p.). É difícil para os trabalhadores/consumidores perceber que as engrenagens opressivas da sociedade dita livre - de indivíduo e mercado livres e superabundância de produtos e prazeres - funcionam como uiaras do encantamento, dissimulando a crueldade da produção de mercadorias geradora de sofrimentos humanos: “[...]a maioria dos sofrimentos humanos normais tende a brotar, hoje, da superabundância de possibilidades, mais que da profusão de proibições, como costumava ocorrer no passado" (BAUMAN, 2011, p. 57). Novamente, pela ideologia da individualização, o indivíduo é responsabilizado por uma culpa que não é dele e da qual ele é vítima e não percebe o cinismo, a armadilha. A sociedade exime-se de responsabilidades que são dela própria: "no cenário desregulamentado e privatizado, centrado em preocupações e buscas consumistas, a responsabilidade sumária pelas escolhas - pela ação que segue a escolha e pelas conseqüências dessas ações - é lançada em cheio nos ombros dos atores individuais" (idem, p. 56).

A qualidade de vida das famílias dos trabalhadores apresenta disparidades extremas, determinadas tanto pela divisão entre as classes sociais, quanto entre frações de classe, entre trabalhadores qualificados e não qualificados. $O$ argumento em torno da intelectualização dos trabalhadores, na dita sociedade do conhecimento, não expressa de forma alguma a emancipação que possa eliminar a separação entre os trabalhadores que operam com as mãos e os trabalhadores intelectuais e em funções de comando. A homogeneização dos trabalhadores, por efeito do processo de qualificação, não atende às necessidades de emancipação geral e não elimina as disparidades e antagonismos. As novas formas de gestão e qualificação do trabalho são partes de um programa internacional que utiliza o aumento da produtividade do trabalho para maximizar, mundialmente, a taxa de lucro. A qualificação para a competitividade encontra inspiração e justificativa em ideologias da individualização, de modo que o indivíduo se sinta o único responsável pela sua qualificação e futuro bem sucedido. Pela Teoria do Capital Humano, o indivíduo é livre e a sociedade, justa, regida pela lei da oferta e procura. Cabe ao indivíduo e suas decisões a responsabilidade pela sua inserção e sucesso (ou fracasso). "A teoria do capital humano, em seu revigoramento, no contexto da mundialização do capital, reaparece recheada com os conceitos de competência, empregabilidade e sociedade do conhecimento, entre outros" (BATISTA, 2003, p. 169). Essa nomenclatura otimista, desde o esplendor da economia dos EUA, no pós-Segunda Guerra Mundial, vem inventando nomes para a abundância e promessas de prazer e felicidade: sociedade do não-trabalho, do lazer, flexível, do conhecimento, pós-capitalista, pós-moderna, etc. A educação está entre as cobiçadas áreas lucrativas. Banco Mundial, BID, UNESCO, CEPAL, OIT, etc., disseminam teorias de que, pela educação, o indivíduo possa garantir sua empregabilidade e que o investimento na educação possa reverter as desigualdades sociais. Tais teorias estão longe de ter validade para soluções universais, embora sejam aplicáveis a projetos individuais, sujeitos à seletividade social e aos interesses do capital no mão-de-obra demandada pelas tecnologias.

Conforme o Censo de 2010, foi de $\mathrm{R} \$ 2.130,95$ o "valor do rendimento nominal médio mensal de todos os trabalhos das pessoas de 10 anos ou mais de idade, ocupadas na semana de referência, com rendimento de trabalho - Total", no município de Maringá (IBGE, 2010). Tal rendimento médio corresponde a quatro vezes o salário mínimo, de $\mathrm{R} \$ 510,00$, à época. Dados referentes ao rendimento médio não são representativos dos pobres da cidade, cuja renda está muito abaixo da média e pouco difere da população brasileira concentrada nas faixas mensais de até 1 salário mínimo $(32,7 \%$, no país) e até 2 salários mínimos (72\%, no país), conforme o censo de 2010. De um lado, o elevado produto interno bruto e alta lucratividade para o capital, e, de outro, a base da pirâmide, um 
enorme contingente de trabalhadores entre a pobreza e a miséria. O senso comum assustase com as remunerações dos políticos e os valores roubados por corrupção, que não passam de uma pequena ponta do iceberg, ou com o maior salário da TV Record (3 milhões de reais, por mês, como divulgado pela imprensa), e pouco se dá conta da dimensão incomensurável do patrimônio que um megainvestidor pode acumular, em poucas décadas, somando valores médios mensais gigantescos - cerca de trinta mil salários mínimos, isto é, acima de 20 milhões de reais, por mês!!! - o que levou um renomado sociólogo brasileiro a chamar tal engenhosidade de gangsterismo.

As crianças e pais/responsáveis entrevistados situam-se na base da pirâmide social, a do trabalho simples, muito contrastante, pela acentuada distância entre trabalho simples e trabalho complexo, bem como entre estes e o trabalho dos intelectuais, dirigentes de setores público e privado, e grandes proprietários. A população ocupada concentra-se em setores com baixos níveis de qualificação do trabalho, como o comercial, que confere à cidade status de pólo atacadista e varejista. Maringá é quase toda urbana (350.653 habitantes = 98,20\% da população total), com minúsculo contingente rural (6.424 habitantes) (IPARDES, 2012, p. 11). Na população ocupada (195.136 pessoas) segundo as atividades econômicas, os trabalhadores intelectuais concentram-se nos setores da Educação (13.727), Atividades profissionais, científicas e técnicas (9.569), Saúde e serviços sociais (9.263), totalizando 32.569 pessoas. A população dos setores em que predomina a força de trabalho basicamente manual, com menor, baixa ou nenhuma qualificação, é muito elevada: são 127.642 pessoas $(65,4 \%)$, distribuídas pelos setores de Comércio e Reparação de veículos, automotores e motocicletas (45.420); Indústrias de transformação (28.813); Construção (13.074); Serviços domésticos (9.917); Transporte, armazenagem e correio (8.341); Alojamento e alimentação (7.228); Agricultura, pecuária, produção florestal, pesca e aqüicultura (4.249) e Atividades mal especificadas (10.700) (IPARDES, 2012, p. 17).

Com a reestruturação produtiva, alguns setores apresentam uma tendência à homogeneização, que atenua a distância de conhecimentos técnicos entre trabalhadores de menor qualificação e trabalhadores qualificados detentores de saber de ofício, dentro de um mesmo setor, como a microeletrônica, ofício de ferramenteiro, torneiro mecânico, fresador, etc. No entanto, percebe-se a persistência da dialética qualificação versus desqualificação. Há um mito em torno da qualificação profissional, uma vez que esta não constitui um processo único, exclusivo, e não se destina ao benefício dos trabalhadores, embora, o trabalhador não possa qualificar-se sem que, para isso, tenha que qualificar-se para o capital. Observe-se, ainda, que o processo envolve, contraditoriamente, qualificação teórica e desqualificação prática, ocultando a disputa do controle do processo de trabalho. $\mathrm{O}$ trabalhador fica mais subordinado ao controle do capital. Trata-se da "substituição de uma forma de conhecimento prático por outra forma de conhecimento fundamentada em princípios tecnológicos e mais subordinada ao controle do capital” (JÚLIO, 2003, p. 125).

As teorias de Hobbes (necessidade da coerção) e de Freud (repressão dos "instintos primários", para atender ao princípio de realidade) parecem perder rigor, quando ciência e tecnologia, na sociedade afluente, levam a crer que o controle social não seja tão necessário. No entanto, a liberação e expansão das pulsões e prazeres, no interesse do capital, permanecem articuladas com a liberação de forças destrutivas. O capitalismo tardio ainda se serve da "mais-repressão" ("repressão desnecessária"), como instrumento de manutenção e reprodução das formas de opressão e dominação (MARCUSE, 1968a). Uma observação de Bourdieu, nos anos 80, é confirmada, hoje, por Bauman: a coerção vem sendo substituída pela estimulação, persuasão prazerosa e sedução (BAUMAN, 2011, p. 56). Isso facilita a servidão voluntária, modo destrutivo da condição humana. Marcuse, em Libertação da sociedade afluente (conferência ministrada em 1967), já comentava o paradoxo da necessidade de libertação para quem não a deseja: 
Em relação a hoje e à nossa própria condição, creio que estamos diante de uma situação nova na história, porque temos que ser libertados de uma sociedade rica, poderosa e que funciona relativamente bem[...] $\mathrm{O}$ problema que enfrentamos é a necessidade de nos libertarmos de uma sociedade que desenvolve em grande medida as necessidades materiais e mesmo culturais do homem - uma sociedade que, para usar um slogan, cumpre o que prometeu a uma parte crescente da população. E isso implica que enfrentamos a libertação de uma sociedade na qual a libertação aparentemente não conta com uma base de massas. (MARCUSE, 1968b, s/ p.)

A condição subjetiva prazerosa da massa de trabalhadores é expressão da deterioração da mente e sentimentos, na sociedade (totalmente) administrada, através de bens culturais que a Teoria Crítica chama de "indústria cultural". São tipos de satisfação, isolamento e redes sociais (ou sociabilidade instrumentalizada) que conduzem o indivíduo à insensibilidade e mutilação do pensamento. Na TV, uma cena de outro mundo, o de três milhões de crianças que morrem de subnutrição, anualmente, aparece como um mundo separado, como se ele não fosse produzido pela mesma estrutura produtiva mundial que privilegia grande parte da população com enganosos edens e analgésicos, em sociedades afluentes, tecnológicas, avançadas.

Aumenta o poder destrutivo do capital, ampliando o sofrimento, sob formas variadas, em todas as classes sociais. Opressão e violência não têm natureza biológica, pois são expressões da produção social, construções históricas. "Não há nenhuma história universal que conduza do selvagem à humanidade, mas há certamente uma que conduz da atiradeira até a bomba atômica" (ADORNO, 2009, p. 266). Admitindo a possibilidade histórica da emancipação humana, a contemporaneidade insiste na regressão, contra a efetivação plena da bondade humana. A escalada da produção destrutiva está instalada no aparato militar e na administração mundial da reprodução e ampliação do capital que necessita daquele aparato. A violência histórica persiste, nas sociedades democráticas, onde a estrutura produtiva afluente resiste às transformações radicais que poderiam reorientar o progresso na direção das necessidades humanas. A vida material e afetiva das crianças é presa de uma cultura degradada, como parte da persistente história universal de antagonismos e contínua violência, uma espécie de lei de conservação da violência.

\section{Segurança ontológica e resistência à ordem social}

Relacionamentos conflituosos entre os pais, separações mal resolvidas, mal conduzidas, reconstituições familiares, desempregos, trabalhos desgastantes, tudo isso contribui para um quadro de ansiedades, onde a criança não sabe qual sua posição, no turbilhão dos acontecimentos, e como se desenrolará seu futuro. Isso compromete um elemento fundamental de sua constituição psíquica, que Giddens (2002) denomina "segurança ontológica", processo cognitivo-emocional que faz mediações entre o mundo externo e o mundo interno da criança.

A ansiedade referente à incerteza do futuro é experimentada de diferentes formas pela maior parte das crianças que nos relataram suas histórias. A ansiedade consuma-se nas relações sociais mais imediatas das crianças, no seio da família, na escola, nas relações de pares, onde ela busca seu reconhecimento existencial (ôntico), social, enfim, autoafirmação. A incerteza do futuro é constituída e constituinte do presente, através de uma trajetória de vida - um habitus - que integra o passado e o futuro na experiência presente (BOURDIEU, 2001). Diz respeito, nesse sentido, à experiência concreta da criança. 
A segurança ontológica consiste em uma fé na coerência da vida, que permite ao indivíduo superar as transições, crises e circunstâncias de alto risco que aparecem em seu percurso. É uma "confiança no fundamento existencial da realidade num sentido emocional, e de certa forma também no cognitivo, que se funda na crença na confiabilidade das pessoas, adquiridas nas primeiras experiências da criança" (GIDDENS, 2002, p. 41). Constitui o "o nexo original de onde emerge uma orientação cognitivo-emocional combinada em relação aos outros, ao mundo dos objetos e à auto-identidade" (idem). De fato, a segurança ontológica tem origem na "confiança básica", "desenvolvida através da atenção amorosa das primeiras pessoas a cuidarem da criança, a confiança básica liga de maneira decisiva a auto-identidade à apreciação dos outros" (idem). De acordo com Erikson, a "confiança básica" consiste na conversão, na formação psíquica da criança, de uma "predizibilidade exterior" em uma "certeza interior", a partir de uma persistência, continuidade, uniformidade, coerência da vida social, que permita à criança apreender e antecipar o mundo externo no seu mundo interno, através de uma correlação confiável (ou fidedigna) entre ambos. Assim, a criança é tomada de uma sensação de segurança e a primeira demonstração de uma confiança básica na criança é "sua voluntária disposição em deixar a mãe de lado sem demasiada ansiedade ou raiva" (ERIKSON, 1971, p. 227). Isso permite à criança um "espaço potencial" para o desenvolvimento de sua autonomia; de uma identidade própria, separada dos pais, através da aceitação de sua ausência, pela fé de que eles vão voltar (GIDDENS, 2002).

O "espaço potencial" e a "confiança básica" ligam-se "de maneira essencial à organização interpessoal do tempo e do espaço", motivo pelo qual, o "hábito" e a "rotina" desempenham um papel fundamental, desde os primeiros dias de vida da criança. Possibilitando que a criança organize sua experiência social, a ligação com um mundo estabilizado de pessoas e objetos, o hábito e a rotina são, assim, defesas eficazes contra a ansiedade (GIDDENS, 2002, p. 42). A criança está "o tempo todo à beira de uma ansiedade impensável": ela não é um ser, mas um "ser sendo" e que deve ser "chamada à existência" pelo ambiente educativo de quem cuida dela (WINNICOTT apud GIDDENS, 2002, p. 42). Dessa forma, "a disciplina da rotina ajuda a constituir um referencial para a sua existência, cultivando um sentido de 'ser' [e de "estar" no mundo], e sua separação do 'não-ser', sendo assim, um elemento da segurança ontológica" (GIDDENS, 2002, p. 42).

O hábito e a rotina são, assim, constituintes de uma "consciência prática" (âncora cognitiva e emocional da segurança ontológica), que capacita tanto à criança quanto ao adulto a agir na vida cotidiana, a "seguir em frente", colocando "entre parênteses" as suas ansiedades existenciais que, de outra forma, podem levá-los a um esmagamento e engolfamento social. De acordo com Giddens (2002, p. 44), a rotina torna-se um "elemento central da autonomia do indivíduo em desenvolvimento", elemento que não apenas não é inimigo da criatividade, "mas a supõe e é suposto por ela". Seu argumento é de que a capacidade criativa é potencializada pela confiança básica engendrada pela rotina. A própria confiança é criativa, encoraja e prepara emocionalmente o indivíduo para "abraçar novas experiências”. O medo, ao contrário, gera esforço e é paralisante, anula o ser.

Um envolvimento criativo com os outros e com o mundo-objeto é quase certamente um componente fundamental da satisfação psicológica e da descoberta de um "sentido moral". Não precisamos recorrer a uma antropologia filosófica misteriosa para vermos que a experiência da criatividade como fenômeno rotineiro é um apoio básico de sentido de dignidade pessoal e portanto de saúde psicológica. Onde os indivíduos não podem viver criativamente, seja por causa da repetição compulsiva de rotinas, seja por que foram incapazes de atribuir plena "solidez" a 
pessoas e objetos à sua volta, provavelmente resultarão tendências melancólicas ou esquizofrênicas (GIDDENS, 2002, p.44).

É preciso considerar, porém, que a confiança básica e a rotina são somente predisposições psicológicas (um suporte emocional) para a criatividade, um substrato favorável. A imaginação e a criatividade, para que se desenvolvam efetivamente, dependem da qualidade dos estímulos sociais ao seu redor, da qualidade de suas relações sociais, dos elementos materiais e simbólicos (arcabouço cultural) da sociedade (VYGOTSKY, 2007). Nesse sentido, a responsabilidade do adulto, no desenvolvimento da dignidade da criança, de potencializar sua atividade vital (essencial), criativa, vai além de organizar suas rotinas, de dar-lhe afeto, mas implica que o adulto seja criativo em suas relações com ela e perante ela, o que depende, na medida do possível, de estímulos à reflexão crítica. Ao que parece, portanto, implica uma resistência à ordem social dominante. Uma relação adulto-criança que se propõe e aceita esse desafio é uma relação de real reapropriação de seu ser (de ambos), de superação do estranhamento e da reificação.

\section{Criança e sociabilidade degradante: resistência à violência, expropriação e isolamento}

O isolamento social, de ordem existencial, ocorre menos pela falta de relacionamentos sociais e mais pela ausência de significação dessas relações, em uma cultura de risco, marcada pelo "retorno da incerteza" na vida cotidiana (GIDDENS, 2002). Um isolamento existencial, social, pela falta de interesses comuns (pelo excesso de interesses antagônicos), em decorrência da complexificação da divisão do trabalho social, pelo estranhamento do ser humano, tanto em relação a si como em relação ao outro, no sentido marxista de alienação, qual seja o do indivíduo expropriado de sua humanidade, de seu ser genérico, universal. Expropriação de sua atividade vital, genuína, e do tempo de vida próprio de sua existência única, específica, essa expropriação arbitrária (expropriação arbitrária) do trabalho e do tempo dos indivíduos (agentes sociais), é a mais comum forma de dominação contemporânea, que pode estar no cerne da ansiedade, da questão da justificação de uma existência humana e social (BOURDIEU, 2001)

Toda essa expropriação arbitrária, que anula o ser enquanto ser estranhado, é perceptível (ainda que a maioria somente o perceba difusa e confusamente) e analisável, em maior ou menor grau, em toda e qualquer das experiências de vida das crianças com que nos deparamos, no trabalho de campo, em seu ambiente escolar e familiar, assim como na experiência relatada por seus pais e professores. A consequência é um marcante quadro de relações mútuas, mas de não reciprocidade, de incompreensão do outro, em que estão ausentes os instrumentos mais elementares de sociabilidade, como o escutar (no sentido de ouvir e compreender) e o diálogo. A obsolescência das regras de sociabilidade tem relações com o individualismo exacerbado e interesses conflitantes que, assim sendo, inviabilizam a compreensão entre os indivíduos pela impossibilidade de empatia (BAUMANN, 2005).

No trabalho de campo, percebemos que, sob um aspecto social e psicanalítico, a "má conduta" atribuída à criança é consequência de uma luta pela própria vida, de autoafirmação ou de "sublimação". Com efeito, diz Erikson, se uma criança sente-se privada, em seu ambiente social, de forma radical, de todas as formas de expressão constituintes de sua auto-identidade, ela se defenderá com desmedida força (instintiva, mesmo animal) contra a sua contingência: "na mata virgem social da existência humana, nenhuma sensação de estar vivo é possível sem um sentimento de identidade do ego. A privação da identidade pode levar ao homicídio" (ERIKSON, 1971, p. 220, grifo nosso). Aquilo que pode parecer 
uma poderosa manifestação de "instinto nu" é quase sempre uma "estratégia desesperada" de sintetizar ou "sublimar da única maneira possível" (idem, p. 221).

Bourdieu (2001, p. 279) atribui as "estratégias de desespero" a um "mundo louco e arbitrário", marcado pelo "desacerto absoluto das antecipações" (perspectivas de futuro), no qual os agentes não conseguem se situar: são condutas que tentam romper com a ordem hostil. Ele ressalta ainda que há uma "lei de conservação da violência", causada pela inclinação à violência daqueles expostos, precocemente, à mesma:

todas as pesquisas médicas, sociológicas e psicológicas atestam que o fato de estar exposto a maus-tratos na infância (em especial de ser espancado pelos pais) está significativamente associado ao aumento de oportunidade de exercer, por sua vez, a violência contra os outros (e muitas vezes contra seus próprios companheiros de infortúnio) por meio de crimes, roubos, estupros, atentados, e também contra si mesmo, sobretudo com o alcoolismo ou a toxicomania (BOURDIEU, 2001, p. 285)

A esse respeito, contudo, não há outra saída, diz Bourdieu, senão a redução da quantidade global de violência, sobretudo aquela que escapa aos olhares e sanções:

[...]aquela (violência) que se exerce no dia-a-dia, nas famílias, nas fábricas, oficinas, bancos, escritórios, delegacias, prisões, ou mesmo nos hospitais e escolas, e que constitui a "violência inerte" das estruturas econômicas e dos mecanismos sociais substituídos pela violência ativa dos homens (idem).

Constatamos que é admitida por ambas as partes - crianças e pais - a violência física, como uma prática educativa legítima. Desde que "merecida" (justificada), a criança aceita, resignada, a correção pela "surra". Uma criança indignou-se, sim, com uma vizinha que acionou o Conselho Tutelar, após ouvi-la apanhar de sua mãe. É verdade, porém, que na maioria das vezes sentem-se injustiçadas (falta de critérios). De forma geral, no entanto, não há excessos. Os pais dizem que usam meios violentos como "último recurso" para educar a criança. É uma prática que, por vezes, dói mais naquele que bate do que naquele que apanha: uma mãe despediu duas lágrimas durante uma entrevista, ao relembrar da única vez que bateu em seu filho (de onze anos). "Eu não gostei de ter batido nele, não gostei mesmo[...] foi a única vez que fiz isso", disse a mãe.

Mas, como percebemos, a criança cresce em meio à violência cotidiana. Não é só a que sofre em seu corpo físico, mas que sofre aos olhos, aos ouvidos, ao seu plano psíquico. É a violência ("desentendimento") dos pais entre si, não grave, mas constante, como um hábito que se incorpora no habitus da criança. É violência (física ou verbal) entre os pais e outras pessoas, no desrespeito do outro, ameaças constantes. Nesse sentido, embates com parentes são rotineiros, as chamadas brigas ou "rixas" de família. Praticamente, cada criança tem um episódio "fresquinho" desse tipo para compartilhar sem, aparentemente, nenhuma preocupação: "é normal”. Brigas de vizinhos, discussões no trânsito, na escola, com os professores. É pouco que um pai ou uma mãe evitem bater em seus filhos e que os exortem à não violência. Seus atos violentos (mesmo contra outros) "falam" mais alto. A cultura generalizada da violência está na escola, nas crianças entre si, entre elas e os professores. Praticamente, todas foram vítimas (ou praticantes) ou presenciaram casos que elas consideram bullying. A violência está na rua, entre jovens maiores, na criminalidade escancarada, às vistas. Uma criança mora perto da "rua dos drogados", conforme se convencionou chamar, em sua vizinhança. Boa parte das crianças presencia o uso de drogas 
a céu aberto, e quando lhes perguntamos sobre a possibilidade de um mundo melhor, é isso que queriam extinguir: sentem-se ameaçadas. A violência está na mídia: a mídia é a cultura da violência. Não bastasse a violência ao redor, é veículo do fluxo global da violência. Este é um sentimento quase consensual, na população que, no entanto, não consegue decifrar as razões da existência de tanta barbárie. O problema está nas contradições sociais ou é a criança que está com má conduta?

Não se pode negar a importância dos elementos psíquicos na interação social, mas a sociedade comporta estruturas sociais das quais a interação social não dá conta, como a determinabilidade das estruturas sociais sobre a própria reprodução social e o indivíduo, especialmente, a criança. Pouco se pode fazer com opiniões, se a cultura é uma questão de práticas sociais, quando as próprias idéias adquirem força social, material, subjugando as mentes, e não uma questão do pensamento, apenas. "A terapia e a orientação aplicadas por profissionais estão destinadas ao fracasso quando a cultura se recusa a proporcionar desde cedo uma base para uma identidade e quando faltam oportunidades para adequadas regulações ulteriores" (ERIKSON, 1971, p. 221). Acrescente-se que o poder da cultura e a oferta de oportunidades envolvem instâncias materiais e espirituais, a omnilateralidade da emancipação humana. Reduzir contradições sociais à dimensão da linguagem e subjetividade é descartar as objetivações históricas e seu peso sobre as escolhas do indivíduo degradado pela divisão do trabalho social, pela violência inerte das estruturas econômicas e dos mecanismos sociais, que as ciências da sociedade detectam. Estas ciências, por si só, não alcançam as soluções, pois que estas dependem do desenrolar coletivo, histórico, das práticas e linhas de força sociais.

\section{A reflexão crítica, nas práticas educativas parentais}

Ainda que a cultura não ofereça uma base, desde cedo, para a identidade da criança, há algo que a família possa fazer, nesse sentido, pela criança e formação de sua autonomia. Erikson (1971, p. 232) ressalta a "extraordinária importância" da função social da família, sempre que proporciona "o último sentimento forte de identidade cultural" para a criança, na formação de sua auto-identidade (na realização da "síntese de seu ego"). A atuação dos pais (e demais educadores) é de fundamental importância no desenvolvimento da autonomia da criança, a começar por ajudá-la a organizar a sua "anarquia potencial", quando ela se lança na apreensão do mundo ao seu redor, a classificar, compreender, e na formação da "topologia social" do seu ego. E, também, na medida em que o ambiente encoraja a criança a "andar por seus próprios pés" e os adultos protegem-na contra as inexpressivas e arbitrárias experiências de envergonhamento e de dúvida precoce. Pois, o maior risco ao desenvolvimento da criança é não proporcionar a ela "a experiência gradual e bem orientada da autonomia da livre escolha" (idem). Se essa experiência se enfraquecer por uma perda inicial de confiança, a criança voltará contra si mesma todo o seu anseio. "O envergonhamento explora um sentimento crescente de pequenez" (idem, p. 233), que se pode desenvolver quando a criança começa a perceber as dimensões de poder e força que lhe desfavorecem, criando nela um desejo de invisibilidade. Enquanto que, do cultivo de um "sentimento de autocontrole sem perda de auto-estima resulta um sentimento constante de boa vontade e orgulho; de um sentimento de perda do autocontrole e de supercontrole exterior resulta uma propensão duradoura para a dúvida e a vergonha" (ERIKSON, 1971, p. 234).

A promoção da autonomia da criança requer dos pais e adultos que suas próprias ansiedades sejam controladas e seus valores e condutas - pontos de referência fundamentais para a criança - bem como as contradições sociais em que vivem sejam objetos de reflexão crítica. Como esperar isso de seres humanos, agentes sociais imersos nas contradições 
sociais que perpassam o trabalho, família, relacionamentos pessoais e sociais, em geral? Como os pais podem ensinar autonomia para as crianças, sem serem autônomos? Como podem ensiná-las a respeitar o outro, se os adultos estão "enredados" (BOURDIEU, 2001, p. 21-22) no jogo dominante, enclausurados nas objetivações sociais que os tornam estranhos e intimidados entre si?

Nos depoimentos das crianças, verificamos que elas estão expostas à ambigüidade dos critérios e sanções, tanto no ambiente escolar, quanto na família. Sentem-se injustiçadas com isso, não são dotadas de um discernimento claro do que seja o certo e o errado, do que se espera delas, situação agravada nesta era de desmanche e incertezas. Não sabem como agradar, obter reconhecimento, aprovação, auto-afirmação perante o adulto, perante a sociedade. E acabam, por fim, resignando-se com o fato de que não há uma coerência na vida social e de que o seu futuro pode ser qualquer coisa de imprevisível. Pode-se perceber que, praticamente, dois terços dos pais/responsáveis não sabem o que devam ensinar a seus filhos: ao mesmo tempo em que ensinam aos filhos a respeitarem o outro, como um igual, ensinam-nos a serem os melhores (melhores do que os mesmos que devem conceber como iguais?). Ensinam-nos a "ser alguém na vida" (que se esforcem por reconhecimento social, o que significa, como diz Bourdieu (2001), enredar no jogo social, capitalista), para que não sofram, para que não sejam pisados, humilhados. Talvez, por isso, essas mesmas crianças não sabem se são "alguém na vida", deixando subentendido que essa é uma possibilidade futura e incerta, mas que, como sabemos, age, efetiva e negativamente, na vida presente, sobre o ser da criança. Vive-se sob o arbítrio, na sociedade hostil à criança. $O$ não reconhecimento ou o falso reconhecimento infligem feridas no ser humano:

"podem ser uma forma de opressão, aprisionando alguém em uma forma de vida redutora, distorcida e falsa". Mais que uma "ausência do devido respeito", esse reconhecimento arbitrário (porque não tem razão de ser, é ilegítimo, é inumano) pode causar "graves feridas, atingindo as suas vítimas com uma mutiladora auto-imagem depreciativa" (TAYLOR apud SOUZA, 2003, p. 35).

As relações entre pais e filhos ainda podem ser consideradas as relações mais duradouras em nossa sociedade líquido-moderna (BAUMAN, 2005). Última trincheira de resistência à fragilidade dos laços humanos, no sentido de "abrir pontes" entre um ser humano e o outro, mas não há garantias, nesse sentido, de que tais relações não sejam também solapadas. Trata-se do investimento mais arriscado que um homem ou uma mulher pode fazer. Uma aquisição sem retorno (será?), somente realizável ao custo de muitos sacrifícios pessoais e do desperdício de muitas "oportunidades" (carreira profissional, viagens, diversões).

As ansiedades e arbitrariedades deterioram as relações sociais e são, de alguma forma, transmitidas às crianças, comprometendo o desenvolvimento de sua autonomia. Valores e regras arbitrárias, instabilidade emocional, critérios ambíguos, relações ambivalentes, como os psicólogos enfatizam, incessantemente, são o ônus implícito nas práticas educativas parentais. Tal ônus não se reduz a uma origem e dimensão interindividual, uma vez que se trata de ônus de várias dimensões, desde a estrutura social ao indivíduo. Como dimensão social, ele reporta à estruturação das relações sociais. Como ensinar às crianças o respeito, o "amor ao próximo", etc., se tais valores, ambíguos e contraditórios, ocultam estruturas sociais que produzem desrespeito, competição, opressão? O desrespeito é uma forma de violência, socialmente, produzida. Ensinar o respeito ao outro exige, no mínimo, mente atenta e sensível à história das sociedades contra todas as formas de opressão. A elevação da razão e sentimentos da criança em torno de um mundo 
melhor, possível, depende do esclarecimento em torno dos paradigmas da emancipação. A dialética do respeito a todas as pessoas, em suas individualidades (diferenças, identidades, etc.) - "aceitá-las como elas são" - coloca em questão se o respeito é devido a todas e quaisquer diferenças e identidades, como aquelas que produzem e reproduzem desigualdades e antagonismos sociais. Na religião, há muita dificuldade em se entender a "ira dos deuses", como a ira de Cristo, ao chicotear e expulsar os vendilhões do templo (Weber observava que a ética protestante exigia a destinação da riqueza para Deus, depois, para o próximo e, por último, para o indivíduo), mas, há uma dificuldade muito maior no entendimento da ira humana contra a cobiça dos velhacos vendilhões do capital. Nas práticas educativas parentais e escolares, há uma contradição, quando se aprende que não se deve desrespeitar o "pobre" (que vende sua força de trabalho) e o "rico" (que compra a força de trabalho), mas, não se aprende a questionar o assalariamento. Não se aprende a questionar a propriedade privada e o assalariamento que, historicamente, são instrumentos para acumular capital e gerar miséria e, dialeticamente, são campos que alavancam a luta pela emancipação. Ensina-se a respeitar a pessoa do grande proprietário, mas, como respeitar o regime de propriedade/gangsterismo que exclui grandes segmentos sociais do acesso à propriedade (terra, moradia, instrumento de trabalho, etc.)? Na ausência de uma efetiva educação contra a barbárie, há pouco ou nenhum espaço para obras de canção e verso que expressam esclarecimento e promoção da emancipação humana. Entre os CDs e DVDs da família e da escola, geralmente, são raras as artes de resistência e contestação, como os Saltimbancos (Chico Buarque), Ideologia e Burguesia (Cazuza), Reengenharia (Itamar Assumpção) ou o Hino do Movimento dos Trabalhadores Rurais Sem Terra (Bogo/Oliveira). A mutilação da razão e dos sentimentos está, por um lado, no estranhamento das necessidades humanas transformado em normalidade e, por outro, na ocultação das objetivações sociais que geram opressão e, assim, não merecem respeito, devem ser repudiadas, banidas. A hipocrisia da ótica do respeito deixa perplexos os defensores da ordem, desde os velhacos do grande capital e todos os conservadores, no esforço de ocultar as contradições e jogar a culpa no indivíduo: por quê um adolescente ateia fogo em índios e moradores de rua? Por quê um pré-adolescente pratica o bullying e chega ao extremo, cometendo o parricídio? Entre as estruturas sociais violentas e a individuação infanto-juvenil, que mediações sociais se interpõem? A moral dominante combate o bullying, pelo respeito tanto à criança vítima quanto à agressora, porém, por quê essa moral é, predominantemente, ocultadora da violência social estrutural e sua determinabilidade sobre a condição do indivíduo que a introjeta? $\mathrm{Na}$ democracia, a censura tolera uma canção com o verso "a burguesia fede" (Cazuza) e ensina-se que é discriminação e ofensa uma criança dizer à outra: "você é uma breguinha fedorenta" ou: _ "eu moro em apartamento e você, na favela". Contudo, debate-se com as crianças por quê suas mentes, em afetividade e entendimento, orientam-se pelas objetivações de divisões e hierarquias sociais? Por quê a fala das crianças reflete as divisões entre favelas e mansões? Por quê as crianças, percebendo e sentindo, desde a infância, as divisões sociais que as separam entre famílias proprietárias e expropriadas, não são socialmente estimuladas a entender e questionar as práticas sociais que dividem os homens e os transformam em "lobos dos homens"? Que espaço existe para a educação contra a barbárie, na estrutura social que gera a ideologia da ascensão social, associando o desejo de escapar do status social dominado à cobiça pelo status dominante para, como se diz, comumente, "se dar bem na vida"? Onde está o esclarecimento sobre a origem, determinabilidade e reprodução das divisões sociais que impedem a individuação emancipadora?

\section{Conclusão}


Foi preciso reconhecer e aplicar alguns pressupostos teórico-metodológicos da Sociologia da Infância, mas também ir além deles, para investigar a hipótese mais proeminente dessa própria sociologia, quanto ao desenvolvimento da autonomia, tanto em meio aos novos discursos produzidos sobre ela e sobre a infância, quanto em sua imersão nos profundos processos de transformação social. Criança e infância eram marginalizadas na pesquisa sociológica, aparecendo implícitas, "sem voz". Cresce o status da criança e infância enquanto uma categoria social a ser abordada diretamente, como objeto de pesquisa por direito próprio, com relativa independência em relação à família e à escola.

Abordar a criança diretamente, "ouvi-la", compreendê-la por si mesma, em seus modos de pensar e de agir, oferece material empírico importante para se compreender as condições sociais de sua auto-afirmação e, assim, problematizar melhor a questão da sua autonomia. Por outro lado, no grupo de crianças que pesquisamos, empiricamente, e a despeito da hipótese da Sociologia da Infância, portanto, no sentido de sua negação, as transformações da sociedade não tem favorecido o desenvolvimento da autonomia da criança, não oferecem condições para sua individuação como auto-afirmação humana. Sua ansiedade e má conduta constantes remetem a esse contexto social que lhe é adverso. As condições sociais que se impõem a essas crianças (porque elas não as criaram e não as dominam) não lhes possibilitam a condição de atores sociais plenos (efetivos), mas as submetem à fatalidade do individualismo exacerbado, que tem raízes na produção social que deteriora o mundo do trabalho e da individualidade. Certa autonomia, assim, é imposta à criança, como condição de sua sobrevivência social e humana e não como favorável à sua auto-afirmação. Uma autonomia negativa é a sua própria resistência à ordem social adversa e que, por vezes, é expressa pela dita "má conduta", pelo seu grito de protesto, insubmissão à sociedade que lhe é hostil. E tudo isso, a despeito e em sentido contrário ao desenvolvimento de sua emancipação jurídica. Se, no âmbito das perspectivas vigentes mais proeminentes da sociologia da infância, a emancipação do estatuto da criança enquanto objeto de estudo, a emancipação jurídica e a autonomia real da criança convergem numa mesma direção (de emancipação efetiva), embora em graus diferentes e através de uma complexa dialética entre si, nosso estudo vem mostrando, em relação ao grupo de crianças pesquisadas, que a autonomia real da criança sofre uma grande defasagem, mesmo, um retrocesso em relação às duas outras categorias.

Verificamos que as relações entre pais e filhos podem favorecer o desenvolvimento de uma autonomia real da criança, promovendo a "segurança ontológica", inclusive o desenvolvimento do pensamento crítico. Se nossa hipótese é positiva no sentido de afirmar a importância, ainda que relativa, dos pais/responsáveis (e educadores, em geral) nesse processo, é negativa no sentido de que esse seja um processo efetivo que esteja ocorrendo em larga escala. Depende de que os pais/responsáveis procurem e, na medida do possível, troquem esclarecimentos, junto às crianças, sobre as contradições sociais em que todos estão imersos. Esse tipo de mediação, pela fala e esclarecimento, é um trabalho forçoso, gradual e contínuo, na superação de mediações sociais "artificiais", como o consumismo, que deformam as relações afetivas. Contudo, isso não substitui as práticas transformadoras dos movimentos sociais. As estruturas sociais que dividem os homens e que se tornam muralhas, pelo quanto constituem uma força total(itária), contém uma dinâmica, contrapartida para a emancipação, cuja universalidade não se efetiva sem a participação de toda a sociedade, inclusive, as crianças, que têm muito a dizer sobre tantas coisas que os adultos não sabem e não sentem. É um estado de recusa, em que sofrimentos de crianças não mais se apaziguem pelo conformismo, com ópios, edens e analgésicos[...]

\section{Referências}


ADORNO, Theodor W. Dialética negativa. Rio de Janeiro: Jorge Zahar, 2009

Educação e emancipação. Rio de Janeiro: Paz e Terra, 1995

ADORNO, Theodor W. e HORKHEIMER, Max. Dialética do esclarecimento. Rio de Janeiro: Jorge Zahar, 1985

BATISTA, Roberto Leme. Reestruturação produtiva, ideologia e qualificação: crítica às noções de competência e empregabilidade. In BATISTA, Robeto Leme e ARAÚJO, Renan (orgs). Desafios do trabalho: capital e luta de classes no século XXI. Londrina: Práxis; Maringá: Massoni, 2003, p. 143-172

BAUMAN, Zygmunt. Amor líquido. Rio de Janeiro: Zahar: 2005

A ética é possível num mundo de consumidores? Rio de Janeiro: Zahar,

2011

Modernidade líquida. Rio de Janeiro: Zahar: 2001

BOURDIEU, Pierre. Meditações pascalianas. Tradução Sérgio Miceli. Rio de Janeiro: Bertrand Brasil, 2001

O DIÁRIO do Norte do Paraná. Sobra emprego e falta qualificação. Maringá, 19.05.2013, p. A1

DUARTE, Newton. A contradição entre universalidade da cultura humana e o esvaziamento das relações sociais: por uma educação que supere a falsa escolha entre etnocentrismo ou relativismo cultural. In: Educação e pesquisa, São Paulo, v. 32, n.3, p. 607-618, set./dez. 2006. Disponível em: http://www.scielo.br/pdf/ep/v32n3/a12v32n3.pdf - Acesso em: 11 mar. 2012

ERIKSON, Erik. Infância e sociedade. Rio de Janeiro: Zahar Editores, 1971

GIDDENS, Anthony. Modernidade e identidade. Rio de Janeiro: Zahar, 2002

GONZÁLEZ, Jorge Cammarano. Trabalho e cotidiano. In: BATISTA, Roberto Leme e ARAÚJO,

Renan (org.). Desafios do trabalho: capital e luta de classes no século XXI. Londrina: Práxis;

Maringá: Massoni, 2003, p. 55-79

IBGE - INSTITUTO BRASILEIRO DE GEOGRAFIA E ESTATÍSTICA. Censo 2010. Disponível em: http://www.censo2010.ibge.gov.br/apps/areaponderacao/index.html Acesso em: 23 jul. 2012

IPARDES - INSTITUTO PARANAENSE DE DESENVOLVIMENTO ECONÔMICO E SOCIAL. Caderno estatístico: Município de Maringá. Junho, 2012. Disponível em:

http://www.ipardes.gov.br/cadernos/Montapdf.php?Municipio=87000\&btOk=ok Acesso em: 23 jul. 2012

JAMESON, Fredric. Pós-modernismo: a lógica cultural do capitalismo tardio. São Paulo: Ática, 1996

JÚLIO, Marcelo. Crise do capital, reestruturação produtiva e qualificação. In: BATISTA, Roberto Leme e ARAÚJO, Renan (orgs.). Desafios do trabalho: capital e luta de classes no século XXI. Londrina: Práxis; Maringá: Massoni, 2003, p. 115-141

LUCENA, Eleonora de. Páginas de sangue. Os livros pensam a violência urbana. Folha de São Paulo, São Paulo, 29.07.2012, Ilustríssima, p. 4-5

MARCHI, Rita de C. A radicalização do processo histórico de individualização da criança e a "crise social" da infância. Braga: Universidade do Minho, Instituto de Estudos da Criança, 2009. Disponível em http://cedic.iec.uminho.pt/Textos_de_Trabalho/menu_base_text_trab.htm. Acesso em: 3 jan. 2013

MARCUSE, Herbert. Eros e civilização: uma interpretação filosófica do pensamento de Freud. Rio de Janeiro: Zahar, 1968a

Introdução. A paralisia da crítica: sociedade sem oposição. In: A Ideologia

da sociedade industrial. Rio de Janeiro: Zahar, 1982, p. 13-22 
Liberation from the Affluent Society (1967 lecture in London). In: COOPER, David (ed.). The Dialectics of Liberation. Harmondsworth/Baltimore: Penguin, 1968b, p. 175-192. Disponível em: http://www.marcuse.org/herbert/pubs/60spubs/67dialecticlib/67LibFromAfflSociety.htm Acesso em: 7 jul. 2012

Novas fontes para a fundamentação do materialismo histórico. In Idéias sobre uma teoria crítica da sociedade. Rio de Janeiro: Zahar, 1972

MARTINS, José de Souza. Exclusão social e a nova desigualdade. São Paulo: Paulus, 2003

MARX, Karl. Manuscritos econômico-filosóficos. Disponível em: http://www.marxists.org/portugues/marx/1844/manuscritos/index.htm (Arquivo Marxista na Internet / MIA), 2007. Acesso em: 2 ago. 2011 Também disponível em: http://focouem.blogspot.com/

Grundisse: Manuscritos econômicos de 1857-58: esboços da crítica da economia política. Tradução Mario Duayer. São Paulo: Boitempo Editorial, 2011.

MARX-ENGELS. Sobre literatura e arte. São Paulo: Global Editora, 1979

OLIVEIRA, Francisco de. Política numa era de indeterminação: opacidade e reecantamento. In: OLIVEIRA, Francisco de e RIZEK, Cibele Saliba (Orgs.). A era da indeterminação. São Paulo: Boitempo (Coleção Estado de Sítio), 2007, p. 15-45

OLIVEIRA, Rosiska Darcy de. Reengenharia do tempo. Trigésima octava reunión de la Mesa Directiva de la Conferencia Regional sobre la Mujer de América Latina y el Caribe - CEPAL / NACIONES UNIDAS. Panel: Políticas de protección social, economia del cuidado y equidad de gênero. Mar del Plata, Argentina, 7 y 8 de septiembre del 2005, disponível em http://www.eclac.cl/mujer/reuniones/mesa38/R_Darcy.pdf Acesso em: 28 jul. 2012

RODRIGUES, Ana Lúcia et alii. Análise da ocupação residencial na região metropolitana de Maringá: a construção e aplicação de uma tipologia. In RODRIGUES, Ana Lúcia e TONELLA, Celene. Retratos da região metropolitana de Maringá: subsídios para a elaboração de políticas públicas participativas. Maringá: Eduem, 2010, p. 17-39

SOUZA, Jessé. A construção social da subcidadania: para uma sociologia política da modernidade periférica. Belo Horizonte: Editora UFMG; Rio de Janeiro: IUPERJ, 2003.

TEIXEIRA, Francisco. Marx, ontem e hoje. In TEIXEIRA, Francisco e FREDERICO, Celso. Marx no século XXI. São Paulo: Cortez, 2009

VIGOTSKI, Liev S. A Formação social da mente. São Paulo: Martins Fontes, 2007

\footnotetext{
${ }^{1} \mathrm{O}$ presente texto incorpora resultados parciais da pesquisa de mestrado de Douglas Facci e contribuições de Luiz Giani, orientador.

2 Mestre em Ciências Sociais, pelo Programa de Pós-Graduação em Ciências Sociais - Mestrado, da UEM, com dissertação sobre a experiência da criança na contemporaneidade. Doutorando do Programa de PósGraduação em Fundamentos da Educação, da UEM.

${ }^{3}$ Mestre em sociologia (UNICAMP) e doutor em História (UNESP/Assis), com tese sobre nacionalismo e realismo socialista na música brasileira. Docente, em Teoria Crítica da Sociedade, no Programa de PósGraduação em Ciências Sociais - Mestrado, da UEM.

4 Extraído de "Che gélida manina", do libreto de Giacosa e Illica para a ópera "La Bohème" (1896), de Puccini. O libreto baseia-se nas "Cenas da vida de boêmia" (1848), de Henri Murger, que vivenciou a pobreza e narrou a vida boêmia anti-burguesa, no período das Revoluções de 1848, em Paris.
}

Recebido: dezembro-13 Aprovado: outubro-14 